\title{
YOUTH UNEMPLOYMENT: A SERIOUS PROBLEM FOR YOUNG ITALIANS NEET AND A COMPARISON WITH THE SOCIAL EXCLUSION CONDITION
}

\author{
Iacopo ODOARDI ${ }^{1}$, Assia LIBERATORE ${ }^{2}$ \\ ${ }^{1}$ University of Chieti-Pescara, Pescara, Italy ${ }^{2}$ Scuola Web Italia, Pescara, Italy
}

\begin{abstract}
The spread of the NEET (young people not in education, employment and training) phenomenon in Italy is largely due to the recession that has exacerbated the structural problems of the labor market, worsening job opportunities and contractual conditions, particularly for young people. We analyze how the level of youth unemployment (YUR) influences the number of young NEETs, both as a direct cause and through the risk of discouraging young people, considering the endogeneity issue. We also analyze the role of YUR and other control variables characterizing the youth condition on the social exclusion rate, since the NEET status is comparable to a form of social exclusion. More information comes from the comparison between two divergent macro-areas: the wealthy Center-North and the less developed South of Italy. The results show that the causes of the two phenomena are different in the years of recession. YUR has a predominant effect on NEET, particularly in the less developed area.
\end{abstract}

Key Words: NEET, youth unemployment, social exclusion, regional dualism, North-South divide.

\section{Introduction}

The growing NEET phenomenon in advanced economies raises important questions for scholars on how to slow down the inactivity status of young people (Odoardi 2020). In general, the increase in the number of youth NEET in the postcrisis years is due to a series of concomitant causes, including the difficulty of adapting rapidly to broader socioeconomic changes (Rahman 2007), new lifestyles imposed by the society (Furlong 2008) and the prolonged youth unemployment that affects the transition period at the end of the studies (Quintini and Manfredi 2009), as analyzed in the economic literature.

Italy is a country widely affected by this problem with important social and economic implications (Eichhorst and Neder 2014). The inactivity of young people is explained by the difficulties in the labor market (Bruno et al. 2014), especially for the occupational levels (Scarpetta et al. 2010) and mainly in some less favored regions (Bacher et al. 2017). The labor market in Italy is also characterized by a low recognition of higher education, that does not guarantee a better job security (Sergi et al. 2018), and by a low-tech economic specialization (European Union 2013) that does not favor and encourage investment in human capital.

Our aim is to analyze the role of the unemployment on the NEET phenomenon in Italy, using regional data and controlling for several aspects characterizing the habits and the socioeconomic background of young Italians - influencing the transition to adulthood in a recessionary period - by detailing the analysis in the two main divergent macro-areas, i.e., Center-North and South. In addition, knowing that YUR can be considered a substantial part of the NEET problem, we also take into account the endogeneity problem that could exist between the two variables, thus assuming the possibility of observing YUR as a source of discouragement for those affected and for those who might be affected, favoring the inactivity of young people. 
Above all, the focus on YUR is due to its predominant role in contributing to the NEET risk in many countries. This contribution is suggested by the large share of the NEET rate explained by the spread of unemployed young people (Carcillo et al. 2015). In this framework, we must consider that Italy is affected by serious problems in the labor market (Pastore 2015), especially in the "poor" South (Demidova et al. 2015). Our research question is as follows: Considering the strong differences in the Italian macro-areas and thus in the local labor markets, what is the effect of YUR on the NEET rate in the postcrisis years in the Center-North and in the South?

We analyze the Italian regions for several reasons. (i) The consideration of two historically divergent contexts (Salvemini 1955) allows us to compare two areas that diverge in economic and social terms (Daniele and Malanima 2007, Odoardi and Muratore 2018), as Italy represents one of the most studied cases of the "North-South divide" (Odoardi and Muratore 2019). (ii) Despite a profound gap in the NEET rates at the expense of the less developed southern regions ${ }^{1}$, accompanied by a poorer economic performance and a lower endowment of human capital, we observe the highest relative increase in the central-northern area ${ }^{2)}$ during the worst years of economic recession. (iii) Italy is a country in which the NEET phenomenon is rapidly growing, probably influenced by the scarce attention paid to the investments in human capital (traditionally poor, Wolff 2000), which places Italian workers as poorly educated and less prepared in comparison to other advanced economies (OECD 2018), while they are affected by a serious problem of unemployment and youth precariousness (Armano and Murgia 2014, Mussida and Sciulli 2018). (iv) In Italy, the relevance of the local labor markets to a young person's status gains importance in the light of a low social mobility (Di Pietro and Urwin 2003), which we expect that could lead disadvantaged young people to adopt the inactivity status. $(v)$ The analyzed period can help to reveal important policy indications for the most atrisk contexts due to the serious effects of the recessionary period on the regional labor markets (Bruno et al. 2014), which contribute to the increase in precariousness, unemployment and, in general, the deterioration of the socioeconomic condition for many young people at risk of NEET (Bell and Blanchflower 2011).

The economic literature explains the NEET phenomenon to be influenced by, in addition to the aforementioned changes in the society and individual problems, the family cultural and economic background (Gorard 2010, Alfieri et al. 2015), which can encourage young people to find a job or to continue their studies. We control this aspect by using variables suggested by the economic literature. Other original aspects of our work are the consideration of different aspects that characterize the Italian context (e.g., taking into account the difficult economic conditions that impose a delay in the creation of a new family, Cavalli and Galland 1996), with a focus on the postcrisis period, and the risk of reverse causality between NEET and YUR.

The current need to decrease the number of inactive young people, knowing that the inactivity status brings long-term social and economic consequences (Ferrie 2001), drives us to investigate remedies from different points of view. In fact, if weaknesses from the point of view of education (also observable in experience and work skills) can make social inclusion more problematic (Bynner and Parsons 2002), it seems useful to compare NEET to the phenomenon of social exclusion in the search of remedies addressed to young people at risk of becoming NEET (Thompson 2011). With this aim, the second step of our investigation starts from the fact that the NEET issue can be observed as a sort of "weak version" of social exclusion (Serracant 2014). The variables considered in the analysis of young people's inactivity are used to search for the causes that lead to the risk of being socially excluded. The aim is to observe whether, in the Italian case, similarities are present in the causes leading to the two phenomena, which

1) The 2017 NEET rates (15-24 years) are approximately 15\% in the Center-North regions and more than $27 \%$ in some South regions (Istat data).

2) The increase of the NEET rate (15-24 years) from 2007 (before the crisis) to 2013-2014 (peak) was more than 7 percentage points in the Center-North and approximately 5 in the South (Istat data). 
would presuppose similar policy interventions to limit the two social problems.

The paper is arranged as follows. The following section proposes a brief reconstruction of the NEET issue with a focus on Italy, the role played by YUR, and the connections with the risk of social exclusion. Next, we describe the methods used in the panel data analysis, followed by the presentation of the variables. We compare the results of different methods and we conclude with some policy implications in the last two sections.

\section{A brief explanation of the NEET Phenomenon}

Young people who are no longer included in a school or training course and who are not even involved in a work activity are referred to as NEETs. This acronym identifies a heterogeneous group of young people based on the common condition of "being outside" of the educational system and the labor market, where the long-term nature of a such condition may exacerbate difficulties in the reintegration process. A first attempt to define this population was provided by Istance et al. (1994) with the term "Status0"; it was only in the late 1990s that the NEET concept was formally introduced in the UK (Social Exclusion Unit 1999) and it became a key indicator of youth disengagement for other European countries and the Organisation for Economic Co-operation and Development (Marshall 2012, Carcillo et al. 2015). More recently, the NEET rate has been more widely used and reported, e.g., to refer to the target population of the "Youth Guarantee" program (up to 24 years old), regarding Europe (European Union 2013), and national programs such as the "Garanzia Giovani" program (up to 29 years old), by the Ministry of Labor and Social Policies (2014), for Italy.

A review of the literature indicates that the increased attention on the NEET concept has occurred despite some criticisms. The main problem is heterogeneity, which refers to the number of different situations included in the standard NEET group (Furlong 2006), and the identification of various subgroups, even if they are not mutually exclusive. This problem is aggravated by the economic effects of the recent financial crisis; the heterogeneity of the vulnerable groups that compose NEET entails the risk of inaccuracy in the definition of the NEET label (Italia Lavoro 2011).

The NEET status is linked to the role of national institutions (e.g., influencing the "school to work" transition, Istrate et al. 2019), structural and social conditions (e.g., parents' social class, economic status, gender, ethnicity) and other factors related to the personal characteristics of involved young people (Hodkinson and Sparkes 1997, Bynner 2005). In addition, several studies suggest that educational levels and personal skills have marked influences on the probability of becoming NEET (Yates and Payne 2006, Pemberton 2008, Alfieri et al. 2015). However, even if upper levels of education seem to preserve young French and Germans from becoming NEET (the risk of becoming NEET is respectively 4.87 and 3.67 times lower for graduates), such risk is amplified in Italy (1.90) and Spain (1.66) (Ciccarelli and Fabrizi 2017). In contrast, the probability of remaining in the NEET condition decreases with the increasing of age for young Italians, while this is not the case for Germany. In other countries that provide economic and social coverage, the NEET condition tends to be determined by purely family needs, such as the condition of parenthood (9.15 times higher in Germany and 3.79 in the UK) (Ciccarelli and Fabrizi 2017).

\section{From YUR to NEET: a picture of italian youth}

One of the most critical socioeconomic issues in Italy since the 2000s is the high unemployment rate. Data from Istat (Italian National Institute of Statistics) reveal levels of the unemployment rate higher than the precrisis values (from $6.1 \%$ in 2007 to approximately $12 \%$ in 2013-2017), up to reach over $20 \%$ in the southern area in 2014. This critical issue, with severe social implications, has contributed to a progressive increase in the NEET rate since the 
beginning of the crisis in 2007-2008, reaching a peak in 2013-2014. Starting in 2015, the NEET rate began to decline in conjunction with some traces of economic recovery, while remaining steadily above the precrisis values. In 2017, the condition of NEET was lower between people aged $15-19(11.9 \%)$ - mostly still being students - but it reached $31.5 \%$ among people aged 25 -29 .

The situation of young Italians remains worrying due to some national characteristics. First, they suffer the lack of a flourishing labor market, with high and persistent levels of youth unemployment, atypical employment and brain drain (Fratesi and Percoco 2014, Fullin and Reyneri 2015). During the long years of the economic crisis, the problematic access of young Italians to the labor market has inevitably increased the portion of youth with medium-high educational qualifications in the condition of NEET, with a recovery that, in any case, is still absolutely insufficient even for young graduates. In recent years, young Italians have been exposed to hard transitions from school to work, and they have had to cope with a high level of outsiderness, a phenomenon that is also connected to the rapid aging of the Italian working population (Johnson and Zimmermann 2008, Emmenegger et al. 2012, Sergi et al. 2018).

Previously, starting from the mid-1990s, the trends in the Italian labor market and its modernization led to an increased number of employed people (Fellini 2015), but with the progressive stagnation of work productivity, such positive trends had reversed (Comito et al. 2014). Since the onset of the crisis, the growth of labor market outsiders has dramatically emerged, where only a shrinking portion of youth have access to the labor market. In addition, young people who work are often temporarily employed and underpaid, with the lack of future perspectives in working improvement (i.e., the transition to better jobs in the future, Chung et al. 2012).

Following Standing (2011) and Sergi et al. (2018), the increased youth unemployment and precarization arise from a progressive flexibilization of job contracts. This is due to the weakness of the Italian economic and productive structure and to social policies that were dangerous for the young generations (Barbieri et al. 2014). Similar to Spain and Greece, increased disillusionment in Italian working conditions leads young people to be disappointed regarding the limits of their ambitions and goals. Most of them live at home with their parents, but unlike youth in other countries, they are considered unwilling to make sacrifices and they face the stereotypes of "mammoni", lazy, spoiled, "choosy" and "bamboccioni" (Bello and Cuzzocrea 2018). In this framework, the former Minister Fornero's speech (in 2012) advised young Italians: "Non bisogna mai essere troppo "choosy". Meglio prendere la prima offerta e poi vedere da dentro e non aspettare il posto ideale" ("Never be too "choosy". Is it better to start with the first available job - to be able to observe from the inside than to wait for the ideal job").

These criticisms rarely match the scientific analysis because they reflect only sensations or limited available cases (Genda 2007). According to Saraceno (2015), the growing number of Italian NEETs reflects emergent poverty based upon strong territorial and class differences. Compared to Spain, Germany and France, the probability of NEET is higher in Italian poor families that face severe economic difficulties.

In addition, the macro-area differences in Italy are remarkable. According to Istat data, the incidence of NEETs in the southern area is more than double that in the central and northern regions. In the South, the NEET group interested in entering or re-entering the labor market $(77.0 \%)$ is larger than the groups in the North $(60.8 \%)$ and the Center $(67.5 \%$, on Istat data 2017). Thus, Italian NEETs often suffer economic disadvantages, which is in stark contrast to the possible view of them as "choosy". The main reason behind this distorted view of youth is the compensative structure of the Italian welfare system that in some cases does not help in reaching independence (Esping-Andersen 1999). In addition, when public transfers decrease, Italy is a country characterized by a high level of family economic transfers (Ciccarelli and 
Fabrizi 2017). A large part of NEETs live in the family's nest, and they are often members of large families: these facts enable NEETs to continue their "wait-and-see" stance (Ciccarelli and Fabrizi 2017).

Another aspect must be considered in the depiction of young Italians at risk of inactivity. In the same breath, intergenerational caregiving becomes an antidote to social exclusion, particularly for young adults in NEET conditions (Gaspani 2019). In spite of the youth's hardship deriving from the forced renouncement of work, young Italians are preserved by an informal familiarized care model (Naldini 2003): first, because it provides young people both material and emotional backing (Tomassini et al. 2003, Gaspani 2019) and, second, because Italy's family-oriented culture assigns young women a time-intensive role in housework activities (Bianchera and Arber 2007), e.g., a double probability of not participating in work, study or training is present for women (Ciccarelli and Fabrizi 2017).

Despite the strong attachment of young Italians to the family, the persistence of unemployment can also generate tensions and conflicts among family members, arising from economic deprivation and the absence of employment prospects (Patton and Donohue 2001). Even if the family is able to protect young people, it also entails challenges with respect to other social relations.

Fig. 1 shows data on the 2000-2017 YUR and NEET rates for the 5 Italian areas according to the Eurostat grouping. The Northwest, Northeast and Center areas correspond to our CenterNorth group, and the South and Islands areas correspond to our South group (also known as Mezzogiorno). The data highlight that the three central and northern groups report similar values, as do the southern regions and major islands on the other side, thus forming two more extensive homogeneous groups. The two macro-areas are highlighted to the right (southern area, higher values of both variables) and to the left (central-northern area) of the Italian average data.

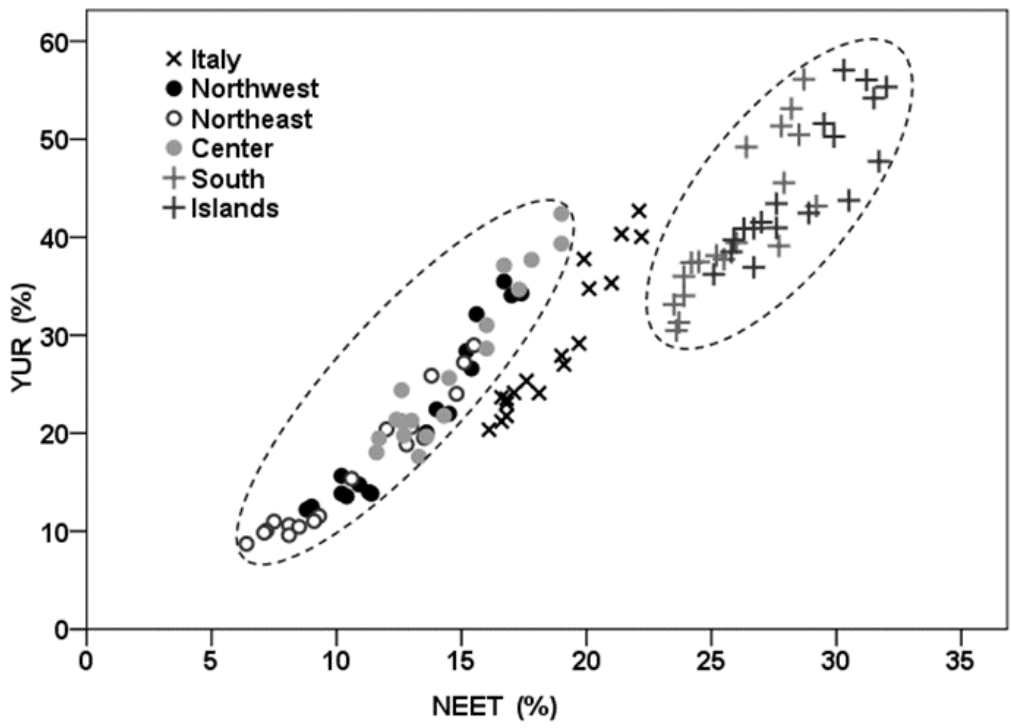

Fig. 1 - NEET rate and YUR for the 5 Italian areas (each point corresponds to one year, 2000-2017)

Source: Authors' elaborations on Eurostat (NEET rate) and Istat (YUR) data 


\section{Methodology}

We study the effects of some independent variables on the NEET rate in the Italian regions and autonomous provinces. We use fixed effects (FE) models, and we perform a two-stage least squares (2SLS) regression to prevent the risk of endogeneity. Our equation can be written as:

(1)

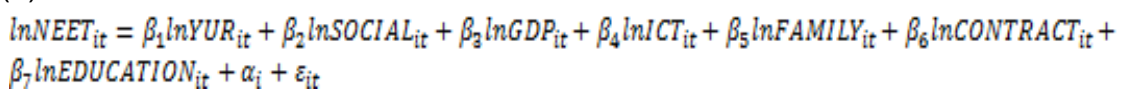

In equation (1), NEET is our dependent variable, and the regressors are presented and explained in the following section. The subscript ${ }^{\tilde{i}}$ represents the 21 regions and autonomous provinces, analyzed for the period 2010-2017 $\left({ }^{t}\right) . \beta_{1 \times n} \beta_{7}$ are the parameters estimated in the section of the results, $\alpha_{i}$ is the unknown intercept for each region, and $\varepsilon_{i t}$ is the error term. The same regressors are used in a second analysis, in which NEET is replaced with EXCLUSION (the social exclusion rate).

Considering the possibility of endogeneity concerning YUR and the NEET rate, in the 2SLS model, YUR is transformed and replaced with a consistent estimator to avoid inconsistent estimates. We consider the unemployment rate (UR) and the long-term unemployment rate (LTUR) as instruments referred to as YUR, which are connected in representing the labor market performances in the Italian regions (Brada and Signorelli 2012). Additionally, the LTUR has an influence on the labor market performance, particularly in Europe, since "some part of cyclical unemployment is turning into structural unemployment" (Brada and Signorelli 2012: 237).

With the aim of controlling for overidentifying restrictions, we present the Hansen's (1982) J test after the results in Table 3 and Table 4. We also present the first-stage F statistic with the aim of testing for the strength of the instruments (the values of this statistic are above 10 , Staiger and Stock 1997).

Furthermore, we test the presence of multicollinearity among the regressors considering the variance inflation factor (VIF). In our regional groups, the highest VIF are 3.13 for the CenterNorth and 5.34 for the South (less than the threshold of 10), the mean VIFs are 2.37 and 3.07, respectively, and the lowest value of tolerance is 0.1873 .

\section{Data}

In this paper, the NEET rate and the social exclusion rate are the two dependent variables (Table 1). The same regressors used in the analysis of the NEET condition at regional level are also considered in a second analysis on the social exclusion risk. Similarly, we consider, in both analyses, the problem of endogeneity of our key variable, YUR.

Numerous studies and definitions exist on the social exclusion phenomenon (Silver 1994). The social exclusion rate refers to people who, mainly for economic or cultural reasons, do not feel integrated or do not have access to the social activities typical of their society or social group (Bhalla and Lapeyre 1997). Social exclusion can be considered connected to the NEET condition since the loss of years of education or lack of work experience can lead to typical weaknesses that make social integration difficult, as discussed by Bynner and Parsons (2002: 302): "In this sense, NEET experience, unaccompanied by other factors, may well be not much 
more than a staging post on the downward path to the bottom of the labor market and social exclusion".

The factors that influence the inactivity of young Italians are many; our regressors consider some aspects of the social background and they are used to test the robustness of the results. The youth unemployment rate (variable: YUR) is a measure of how much the economic crisis of 2007-2008 has hit the labor condition of young people in several advanced economies. Italy has been one of the most affected countries in which not even a high education can help the unemployed young people to find jobs (Scarpetta et al. 2010), in contrast to the findings in other European countries (Istrate et al. 2019).

We consider that social capital (intended as social networks, shared values and trust in the society, SOCIAL) can have a role in opposing the inactivity of young people, for example, favoring the search for work (Kraak 2013) and encouraging the continuation of studies (Fuller 2014). We consider volunteer work as a proxy of social capital (Harper 2002). In addition, social capital is an important aspect in explaining the Italian North-South dualism, and, in particular, we highlight its shortage in the southern area of the country (Putnam et al. 1993).

The GDP per capita (GDP) is a measure of households' wellbeing that influences the risk of becoming NEET, offering more opportunities for young people in the wealthiest families (Bynner and Parsons 2002).

Similarly, we consider the population with a secondary or tertiary educational level (EDUCATION) a proxy of the educational level of parents (Odoardi 2020) and, thus, a measure of abilities, e.g., in orienting children towards cultural understanding (Sullivan 2001) and in favoring the acquisition of skills related to school performance. Consequently, the aforementioned abilities of parents influence the risk of becoming NEET (Bynner et al. 2000).

Proxies of income and parents' human capital represent the broader cultural and economic background of households which has a well-known impact on the studies and working careers of children (Alfieri et al. 2015).

Another aspect influencing inactivity through both the search for work and study concerns the way modern information and communication technologies are used. We consider the rate of homes with broadband connections (ICT) as a proxy of the use of ICTs (information and communications technologies). Among young NEETs, the possibility of using ICTs can be a strength enabling them to keep skills updated or look for a job (Cecchini and Raina 2002, Barbas et al. 2017).

We include data on the percentage of young unmarried Italians aged 18-34 living in their parents' house (FAMILY), as a proxy of an Italian habit of leaving the family of origin late with respect to other countries, and therefore postponing by choice, as well as because of the general economic conditions, the passage to adulthood (Aassve et al. 2001, Alfieri et al. 2015, Mussida and Sciulli 2018).

Finally, we include a measure of the spread of part-time model contracts (CONTRACT). We consider this variable to be indicative of the level of precariousness in the labor market, which is a well-known cause of temporary unemployment and it induces discouragement in the search for work, leading to inactivity (Furlong 2008, Standing 2011), especially for young people (Chung et al. 2012).

For our analysis, we consider two homogeneous groups of regions, namely, Center-North and South. This division (Fig. 2) comprises two well-known divergent areas (Brida et al. 2014). 
The economic literature widely debates the numerous social, cultural and economic gaps (Salvati 2013) between the North area and the South, or Mezzogiorno, which represents the less developed area of the country since the unification in 1861 (Capello 2016). Historically, the regions of the northern area have always been the richest economically, thanks to the opening to foreign trade favored by natural resources and the proximity to European markets (Toniolo 2013), and they have enjoyed a greater endowment of human capital and social capital (Bigoni et al. 2016). In contrast, the southern area has been characterized by an economy based on agriculture for a long time, and despite the numerous extraordinary public interventions for promoting industrialization, the presence of inefficiencies and clientelism has marked its weaker path of development (Felice 2007).

Variables descriptions and sources

Table 1

\begin{tabular}{|c|c|l|c|}
\hline & Variable & \multicolumn{1}{|c|}{ Definition } & Source \\
\hline 1 & NEET & $\begin{array}{l}\text { NEET rate, young people (15-24 years) neither } \\
\text { in employment nor in education and training (\%) }\end{array}$ & Eurostat \\
\hline 3 & EXCLUSION & People at risk of poverty or social exclusion (\%) & $\begin{array}{c}\text { Istat (our } \\
\text { elabora- } \\
\text { tions) }\end{array}$ \\
\hline 4 & YUR & $\begin{array}{l}\text { Youth unemployment rate, persons aged 15-24 } \\
\text { seeking employment on the labor force (in the }\end{array}$ & Istat \\
\hline 5 & GDP & $\begin{array}{l}\text { People aged 14 and over who have been work- } \\
\text { ing for free for voluntary associations or groups }\end{array}$ & Istat \\
\hline 6 & ICT & $\begin{array}{l}\text { Share of households with internet broadband } \\
\text { access (in \% of total households) }\end{array}$ & Istat \\
\hline 7 & FAMILY & People (18-34 years) unmarried, living in a family & Istat \\
\hline 8 & CONTRACT & $\begin{array}{l}\text { Part-time employment incidence (\% part-time } \\
\text { employees over total employment) }\end{array}$ & OECD \\
\hline 9 & EDUCATION & $\begin{array}{l}\text { Population aged 25-64 with secondary or tertiary } \\
\text { education (levels 3-8 ISCED2011 } \% \text { \%) }\end{array}$ & Eurostat \\
\hline 10 & UR & $\begin{array}{l}\text { Unemployment rate, people aged 15 and over } \\
\text { seeking employment vs. the labor force in the }\end{array}$ & Istat \\
\hline 11 & LTUR & $\begin{array}{l}\text { Long-term unemployment rate, share of people } \\
\text { seeking employment for more than 12 months }\end{array}$ & Istat \\
\hline
\end{tabular}

${ }^{a}$ Due to missing data, 2010-2011 values for two regions (Emilia-Romagna and Marche) are replaced with the national average.

International Standard Classification of Education 


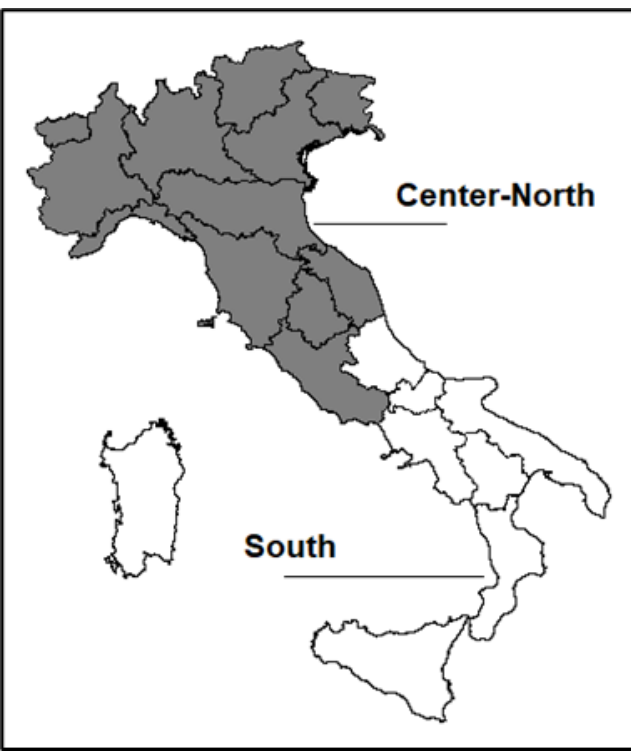

Fig. 2 - The two groups of Italian regions

In particular, the Center-North group is composed of 11 regions (Aosta Valley, EmiliaRomagna, Friuli-Venezia Giulia, Lazio, Liguria, Lombardy, Marche, Piedmont, Tuscany, Umbria, Veneto) and 2 autonomous provinces ${ }^{3)}$ (Bolzano and Trento). The South group is composed of 8 regions (Abruzzo, Apulia, Basilicata, Calabria, Campania, Molise, Sardinia, Sicily).

Table 2

Summary statistics for the two macro-areas in Italy

\begin{tabular}{|l|c|c|c|c|c|c|c|c|c|c|}
\hline & \multicolumn{7}{|c|}{ Center-North } & \multicolumn{5}{c|}{ South } \\
\hline Variable & Min & Max & Mean & Std. Dev. & & \multicolumn{1}{c|}{ Min } & \multicolumn{1}{c|}{ Max } & Mean & Std. Dev. \\
\hline \multicolumn{7}{|c|}{ Dependent variables } \\
\hline NEET & 7.70 & 20.50 & 14.77 & 2.66 & & 13.70 & 34.00 & 25.28 & 5.02 \\
\hline $\begin{array}{l}\text { EXCLU- } \\
\text { SION }\end{array}$ & 8.41 & 30.70 & 18.87 & 4.47 & & 26.44 & 57.75 & 41.74 & 8.20 \\
\hline \multicolumn{7}{|c|}{ Independent variables } \\
\hline YUR & 6.50 & 49.00 & 27.53 & 8.83 & & 26.52 & 65.14 & 46.54 & 8.74 \\
\hline SOCIAL & 6.20 & 27.30 & 13.08 & 4.53 & & 5.00 & 11.20 & 7.29 & 1.58 \\
\hline GDP & $21,889.39$ & $38,550.37$ & $30,109.96$ & $4,032.22$ & & $15,309.73$ & $23,530.68$ & $18,303.58$ & $2,266.99$ \\
\hline ICT & 48.00 & 83.00 & 68.08 & 11.36 & & 34.00 & 81.00 & 60.08 & 12.96 \\
\hline FAMILY & 38.10 & 68.00 & 57.55 & 5.05 & & 60.00 & 75.70 & 67.15 & 2.96 \\
\hline $\begin{array}{l}\text { CON- } \\
\text { TRACT }\end{array}$ & 12.80 & 24.00 & 18.42 & 2.27 & & 10.60 & 20.90 & 16.19 & 2.46 \\
\hline EDUCA- & 50.40 & 71.10 & 62.62 & 4.41 & & 44.50 & 65.10 & 53.11 & 5.58 \\
\hline
\end{tabular}

Source: Authors' elaborations based on Eurostat, Istat and OECD data

3) In Fig. 2, the two autonomous provinces are not divided, and their region (Trentino-Alto Adige) is present. 
In Table 2, we show the summary statistics for the abovementioned groups of regions, demonstrating the differences between the richest regions of the Center-North and the less developed South.

The average income of the South is approximately $60 \%$ of that of the richest regions. In addition, the new technologies that are less widespread, the proxy value of the social capital that is approximately half of that of the Center-North, and the lower share of adults with advanced education show structural gaps capable of influencing the two areas differently. From these gaps, we expect evident differences in explaining the dependent variables - NEET and EXCLUSION - i.e., two social problems for which we observe almost double average values in the South compared to the Center-North.

\section{Results and Discussion}

We present the results of the FE and 2SLS models in Tables 3 and 4, followed by the tests. Table 3 shows the relevant effect of YUR in both areas, highlighting the stronger effect in the South, where the FE model underestimates its relevance. The major relevance of the YUR is evident in the regions where it afflicted over $50 \%$ of young people during the negative peak of 2013-2015 (Istat data), i.e., all southern regions except Abruzzo and Molise.

FE and 2SLS regressions (dependent variable: InNEET)

\begin{tabular}{|c|c|c|c|c|}
\hline & \multicolumn{2}{|c|}{ Center-North } & \multicolumn{2}{|c|}{ South } \\
\hline & FE & 2SLS & $\mathrm{FE}$ & 2SLS \\
\hline InYUR & $\begin{array}{c}0.459^{* * *} \\
(0.064)\end{array}$ & $\begin{array}{l}0.258^{* * *} \\
(0.098)\end{array}$ & $\begin{array}{c}0.632^{* * *} \\
(0.088)\end{array}$ & $\begin{array}{c}0.805^{* * *} \\
(0.127)\end{array}$ \\
\hline InSOCIAL & $\begin{array}{c}-0.073 \\
(0.083) \\
\end{array}$ & $\begin{array}{l}-0.122 \\
(0.101) \\
\end{array}$ & $\begin{array}{l}-0.055 \\
(0.064) \\
\end{array}$ & $\begin{array}{l}-0.072 \\
(0.056) \\
\end{array}$ \\
\hline InGDP & $\begin{array}{l}-0.305 \\
(0.473) \\
\end{array}$ & $\begin{array}{c}-1.084^{\star *} \\
(0.510)\end{array}$ & $\begin{array}{c}0.298 \\
(0.322) \\
\end{array}$ & $\begin{array}{l}0.703^{*} \\
(0.409) \\
\end{array}$ \\
\hline InICT & $\begin{array}{c}0.105 \\
(0.124) \\
\end{array}$ & $\begin{array}{l}0.198^{*} \\
(0.116) \\
\end{array}$ & $\begin{array}{l}-0.048 \\
(0.080) \\
\end{array}$ & $\begin{array}{c}-0.063 \\
(0.071) \\
\end{array}$ \\
\hline InFAMILY & $\begin{array}{c}0.098 \\
(0.146)\end{array}$ & $\begin{array}{c}0.169 \\
(0.157)\end{array}$ & $\begin{array}{l}-0.166 \\
(0.216)\end{array}$ & $\begin{array}{l}-0.317 \\
(0.209)\end{array}$ \\
\hline InCONTRACT & $\begin{array}{l}-0.421^{*} \\
(0.227)\end{array}$ & $\begin{array}{l}-0.407^{*} \\
(0.229) \\
\end{array}$ & $\begin{array}{l}-0.110 \\
(0.129) \\
\end{array}$ & $\begin{array}{l}-0.156 \\
(0.102) \\
\end{array}$ \\
\hline InEDUCATION & $\begin{array}{l}-0.195 \\
(0.408) \\
\end{array}$ & $\begin{array}{l}-0.234 \\
(0.476) \\
\end{array}$ & $\begin{array}{c}0.065 \\
(0.434) \\
\end{array}$ & $\begin{array}{c}-0.004 \\
(0.497) \\
\end{array}$ \\
\hline Constant & $\begin{array}{c}5.694 \\
(4.778)\end{array}$ & & $\begin{array}{l}-1.087 \\
(3.214)\end{array}$ & \\
\hline $\mathbf{R}^{2}$ & 0.6023 & & 0.6992 & \\
\hline $\begin{array}{l}\text { First-stage F } \\
\text { statistic (InYUR) }\end{array}$ & & $\begin{array}{c}56.74 \\
{[0.0000]}\end{array}$ & & $\begin{array}{c}15.18 \\
{[0.0000]} \\
\end{array}$ \\
\hline $\begin{array}{l}\text { Hansen J statis- } \\
\text { tic p-value }\end{array}$ & & 0.3422 & & 0.3797 \\
\hline Obs. & 104 & 104 & 64 & 64 \\
\hline
\end{tabular}

Note: ${ }^{* * *},{ }^{* *},{ }^{*}$ statistically significant at the levels of $0.01,0.05$ and 0.10 Source: Authors' elaborations based on Eurostat, Istat and OECD data 
We also observe unexpected effects of households' socioeconomic and cultural backgrounds. The proxy of parents' human capital does not have an effect in opposing youth inactivity in the considered period. The missing effect of parents' education could be linked to the relatively low level of Italian human capital compared to other advanced economies (OECD 2017b) and the fact that few students have parents with high educational qualifications (OECD 2017a), therefore failing to trigger positive implications. The sign of GDP is negative in the CenterNorth, as expected, by favoring mainly better education opportunities, while a higher economic status favors the NEET condition in the southern area. The effect of GDP in the South could be linked to the presence of irregular work.

The spread of part-time contracts does not discourage young people; indeed, the possibility of finding this type of work, although not the ideal job, probably limits the spread of young NEETs in the Center-North. FAMILY is not influential on the status of NEET, probably because the delay in the transition to adulthood and to independence is typical of the Italian society (Cook and Furstenberg Jr. 2002). In fact, the need to stay in the parents' nest is due to the household acting as auxiliary "welfare" to young Italians (Cuzzocrea 2014). Finally, the low but positive sign of ICT (Center-North) suggests a distorted use of new technologies among the inactive young people.

The results in Table 4 suggest that there are a few points in common between the NEET issue and the social exclusion issue in the considered period. YUR loses its role, which was

FE and 2SLS regressions (dependent variable: InEXCLUSION)

Table 4

\begin{tabular}{|c|c|c|c|c|}
\hline & \multicolumn{2}{|c|}{ Center-North } & \multicolumn{2}{|c|}{ South } \\
\hline & $\mathrm{FE}$ & $2 S L S$ & $\mathrm{FE}$ & $2 S L S$ \\
\hline InYUR & $\begin{array}{c}0.066 \\
(0.092)\end{array}$ & $\begin{array}{c}0.113 \\
(0.124)\end{array}$ & $\begin{array}{c}-0.089 \\
(0.147)\end{array}$ & $\begin{array}{c}-0.299 \\
(0.224)\end{array}$ \\
\hline InSOCIAL & $\begin{array}{c}0.029 \\
(0.119)\end{array}$ & $\begin{array}{c}0.041 \\
(0.132)\end{array}$ & $\begin{array}{c}0.074 \\
(0.107)\end{array}$ & $\begin{array}{c}0.095 \\
(0.106)\end{array}$ \\
\hline InGDP & $\begin{array}{c}-0.164 \\
(0.678) \\
\end{array}$ & $\begin{array}{c}0.019 \\
(0.758) \\
\end{array}$ & $\begin{array}{c}-1.176^{\star *} \\
(0.538) \\
\end{array}$ & $\begin{array}{r}-1.667^{* * *} \\
(0.641) \\
\end{array}$ \\
\hline $\ln I C T$ & $\begin{array}{c}0.174 \\
(0.177)\end{array}$ & $\begin{array}{c}0.152 \\
(0.158)\end{array}$ & $\begin{array}{l}-0.035 \\
(0.134)\end{array}$ & $\begin{array}{l}-0.017 \\
(0.095)\end{array}$ \\
\hline InFAMILY & $\begin{array}{c}0.154 \\
(0.210)\end{array}$ & $\begin{array}{c}0.138 \\
(0.218)\end{array}$ & $\begin{array}{l}0.763^{* *} \\
(0.361)\end{array}$ & $\begin{array}{l}0.947^{* *} \\
(0.374)\end{array}$ \\
\hline InCONTRACT & $\begin{array}{l}0.744^{* *} \\
(0.326) \\
\end{array}$ & $\begin{array}{l}0.741^{* *} \\
(0.330) \\
\end{array}$ & $\begin{array}{c}0.017 \\
(0.215) \\
\end{array}$ & $\begin{array}{c}0.074 \\
(0.256) \\
\end{array}$ \\
\hline InEDUCATION & $\begin{array}{c}-1.355^{\star *} \\
(0.585)\end{array}$ & $\begin{array}{c}-1.346^{* *} \\
(0.542)\end{array}$ & $\begin{array}{c}0.311 \\
(0.724)\end{array}$ & $\begin{array}{c}0.396 \\
(0.687)\end{array}$ \\
\hline Constant & $\begin{array}{c}6.399 \\
(6.852) \\
\end{array}$ & & $\begin{array}{c}11.089^{* *} \\
(5.365)\end{array}$ & \\
\hline $\mathbf{R}^{2}$ & 0.3257 & & 0.2303 & \\
\hline First-stage F statistic (InYUR) & & $\begin{array}{c}56.74 \\
{[0.0000]}\end{array}$ & & $\begin{array}{c}15.18 \\
{[0.0000]}\end{array}$ \\
\hline Hansen J statistic p-value & & 0.5240 & & 0.7277 \\
\hline Obs. & 104 & 104 & 64 & 64 \\
\hline
\end{tabular}

Note: ${ }^{* * *}, * *{ }^{*}$ statistically significant at the levels of $0.01,0.05$ and 0.10

Source: Authors' elaborations based on Eurostat, Istat and OECD data 
predominant in the previous analysis, and the GDP has an effect, as expected, but it is significant only in the South, where the lowest average wealth and income probably make an increase in income necessary to carry out the activities in which young people participate in their society.

The tendency to remain in the family nest with increasing age - perhaps to exploit its economic sustenance and benefits (Mencarini et al. 2017), but not facing the transition to adulthood pushes youth towards social exclusion in the South. The relative growth of part-time contracts (in the total labor contracts), on the one hand, offers employment opportunities but, on the other hand, it does not guarantee the possibility of integrating and fully performing social interactions (Center-North). CONTRACT is also not relevant in the South, in the second analysis. This is a confirmation of the different performances of the two local labor markets (Cracolici et al. 2007), although in an unfavorable broader context of growing flexible contracts (Barbieri and Scherer 2009), which makes it difficult for young people to obtain jobs with permanent contracts and a good pay.

Parents' advanced education, representing abilities in managing their children's study paths and search for work, is relevant only in the Center-North, i.e., the area that enjoys a higher level of human capital. In the South, this effect is not observed, as in no case do we notice a significant role of social capital. The strengthening of social ties and networks is irrelevant in Italy, perhaps not necessary in the North, and it could be ineffective in the South due to its severe scarcity in this area (Putnam et al. 1993), and it thus does not trigger the propagation of positive effects.

Few common variables explain the two phenomena simultaneously (CONTRACT in CenterNorth and GDP in the South), and they always have the opposite sign between Tables 3 and 4 .

\section{Conclusions}

The NEET problem is a serious socioeconomic issue affecting many advanced economies. Italy is, in many ways, a representative case of this situation. This country is plagued by a severe postcrisis recession, strong unemployment, especially among young people, and few resources dedicated to the development of human capital. In addition, Italy represents a strong case of the so-called "North-South problem", since the richest regions of the North have an average income almost double that of the less developed South. However, in both macroareas, the problem of young NEETs is strong and rapidly increasing, causing growing concern about the future conditions of the young people involved or at risk.

In this framework, we have focused on youth unemployment that is an important cause of the NEET phenomenon for several reasons. First, it affects the youth labor market and the difficulty of finding a job. Moreover, when considering the risk of reverse causality between YUR and NEET, YUR becomes a factor discouraging young people and pushing them to inactivity. In addition, considering the postcrisis years, we must consider the influence of the business cycle on YUR (Dietrich and Möller 2016). In fact, a more sensitive response of YUR (with respect to UR) is observed in Europe in the recent financial crisis (Brada et al. 2014).

The effect of YUR on NEET is detected by both the FE and the 2SLS model, and, as expected, the effect is greater in the South, where youth unemployment has reached over $40 \%$ in some recent years (Istat data). The discouragement effect, which we presume to observe mainly by the 2SLS approach (compared with the coefficient of the FE model), indicates that the fear is stronger in the South, where many young people are aware of the difficulties in finding a job which highly qualified people also face. 


\begin{abstract}
We have compared these results by testing the same regressors on the social exclusion rate, with the aim of finding similar causes and therefore setting possible common policy interventions. NEET is connected to social exclusion, and for several reasons, the inactive young tend to become socially excluded. The inability to fully participate in social activities, however, proves to be different from the inactivity conditions of young people typical of the NEET condition, at least in the recessionary years tested in our analysis. In particular, income plays a fundamental role in the poorest regions of the South, where high unemployment makes it difficult for young people to create a new family, and remaining in the family nest contributes to their isolation from the society. In the Center-North, the more efficient labor market provides major employment opportunities, but with contracts that are often inadequate for a lifestyle that allows a full social integration. However, in this framework, the average cultural background of parents seems to have positive effects (probably by favoring the educational path and the active search for work) only in the most developed regions.
\end{abstract}

Other structural weaknesses emerge. Young Italians are not able to exploit new technologies to keep their education up to date or to find a job, while local human capital and social capital are not always able to trigger virtuous circles to help young people. The new contracts that are often aimed at young people, such as part-time contracts, may not be the best solution, but at least in the Center-North, they offer job opportunities. The so-called new precariat (Standing 2011 ) is, in fact, a risk for young people driven to accept temporary and low-paid jobs, causing uncertainty in future conditions (Chung et al. 2012).

From the comparison between the inactivity status of young people and social exclusion, we can affirm that a structural improvement of the labor market, with particular attention to the job opportunities for young people, is a fundamental step in all regions. However, the gravity of the Italian context means that public interventions may not be sufficient in the absence of joint expansive policies (Pastore 2015).

In particular, it seems that only an economic recovery can have any relevance in the South. However, the return to growth cannot guarantee better working conditions in the light of European Union's austerity measures (Brada et al. 2014), so even a marked growth may be ineffective in addressing issues such as NEET or YUR (Bruno et al. 2014).

This work contributes to raising awareness of the relationships between two increasingly serious phenomena, common to less resilient countries. Although limitations are found in the availability of data, which do not allow direct comparisons with the precrisis periods, this study sets a basis for the development of future research that can exploit the knowledge of microdata to outline targeted policy interventions. Furthermore, future research will analyze the results of the already started policies (e.g., "Garanzia Giovani" program in Italy).

\title{
References
}

AASSVE A., BILLARI F. C., ONGARO F. (2001), The impact of income and employment status on leaving home: evidence from the Italian ECHP sample, Labour 15 (3), 501-529.

ALFIERI S., SIRONI E., MARTA E., ROSINA A., MARZANA D. (2015), Young Italian NEETs (not in employment, education, or training) and the influence of their family background, Europe's Journal of Psychology 11 (2), 311-322.

ARMANO E., MURGIA A. (2014), The precariousnesses of young knowledge workers: a subject-oriented approach, Global Discourse 3 (3-4), 486-501.

BACHER J., KOBLBAUER C., LEITGÖB H., TAMESBERGER D. (2017), Small differences matter: how regional distinctions in educational and labour market policy account for heterogeneity in NEET rates, Journal for Labour Market Research 51, 4. 
BARBAS M., BRANCO P., LOUREIRO A., MATOS P. (2017), NEETin with ICT, Universal Journal of Educational Research 5 (4), 537-543.

BARBIERI P., CUTULI G., SCHERER S. (2014), Giovani e lavoro oggi. Uno sguardo sociologico a una situazione a rischio, Sociologia del lavoro 136, 73-98.

BARBIERI P., SCHERER S. (2009), Labour market flexibilization and its consequences in Italy, European Sociological Review 25 (6), 677-692.

BELL D. N. F., BLANCHFLOWER D. G. (2011), Young people and the Great Recession, Oxford Review of Economic Policy 27 (2), 241-267.

BELLO B. G., CUZZOCREA V. (2018), Introducing the need to study young people in contemporary Italy, Journal of Modern Italian Studies 23 (1), 1-7.

BHALLA A., LAPEYRE F. (1997), Social exclusion: towards an analytical and operational framework, Development and Change 28 (3), 413-433.

BIANCHERA E., ARBER S. (2007), Caring and sleep disruption among women in Italy, Sociological Research Online 12 (5), 200-2013.

BIGONI M., BORTOLOTTI S., CASARI M., GAMBETTA D., PANCOTTO F. (2016), Amoral familism, social capital, or trust? The behavioural foundations of the Italian North-South divide, The Economic Journal 126 (594), 1318-1341.

BRADA J., MARELLI E., SIGNORELLI M. (2014), Young people and the labor market: key determinants and new evidence, Comparative Economic Studies 56 (4), 556-566.

BRADA J. C., SIGNORELLI M. (2012), Comparing labor market performance: some stylized facts and key findings, Comparative Economic Studies 54, 231-250.

BRIDA J. G., GARRIDO N., MUREDDU F. (2014), Italian economic dualism and convergence clubs at regional level, Quality \& Quantity 48, 439-456.

BRUNO G. S. F., MARELLI E., SIGNORELLI M. (2014), The rise of NEET and youth unemployment in EU regions after the crisis, Comparative Economic Studies 56, 592-615.

BYNNER J. (2005), Rethinking the youth phase of the life-course: the case for emerging adulthood?, Journal of Youth Studies 8 (4), 367-384.

BYNNER J., JOSHI H., TSATSAS M. (2000), Obstacles and opportunities on the route to adulthood: Evidence from rural and urban Britain, The Smith Institute, London.

BYNNER J., PARSONS S. (2002), Social exclusion and the transition from school to work: the case of young people not in education, employment, or training (NEET), Journal of Vocational Behavior 60 (2), 289-309.

CAPELLO R. (2016), What makes Southern Italy still lagging behind? A diachronic perspective of theories and approaches, European Planning Studies 24 (4), 668-686.

CARCILLO S. FERNÁNDEZ R., KÖNIGS S., MINEA A. (2015), NEET youth in the aftermath of the crisis: Challenges and policies, OECD Publishing, Paris.

CAVALLI A., GALLAND O. (eds.) (1996), Senza fretta di crescere. L'ingresso difficile nella vita adulta, Translated by Della Porta B., Liguori, Naples.

CECCHINI S., RAINA M. (2002), Warana: the case of an Indian rural community adopting ICT, Information Technology in Developing Countries Working Paper, Retrieved from: www.papers.ssrn.com.

CHUNG H., BEKKER S., HOUWING H. (2012), Young people and the post-recession labour market in the context of Europe 2020, Transfer: European Review of Labour and Research 18 (3), 301-317.

CICCARELLI A., FABRIZI E. (2017), Family background and persistence in NEET status, Rivista Italiana di Economia, Demografia e Statistica 71 (1), 29-40.

COMITO V., PACI N., TRAVAGLINI G. (2014), Un paese in bilico. L'Italia tra crisi del lavoro e vincoli dell'euro, Ediesse, Rome.

COOK T. D., FURSTENBERG JR. F. F. (2002), Explaining aspects of the transition to adulthood in Italy, Sweden, Germany, and the United States: a cross-disciplinary, case synthesis approach, The Annals of the American Academy of Political and Social Science 580 (1), 257-287.

CRACOLICI M. F., CUFFARO M., NIJKAMP P. (2007), Geographical distribution of 
unemployment: an analysis of provincial differences in Italy, Growth and Change 38 (4), 649670.

CUZZOCREA V. (2014), Projecting the category of NEET into the future, in: Council of Europe and the European Commission, Perspectives on youth. Volume 1: 2020 - what do YOU see?, Council of Europe Publishing, Strasbourg Cedex, pp. 69-82.

DANIELE V., MALANIMA P. (2007), II prodotto delle regioni e il divario Nord-Sud in Italia (1861-2004), Rivista di politica economica 97 (2), 267-316.

DEMIDOVA O., MARELLI E., SIGNORELLI M. (2015), Youth labour market performances in the Russian and Italian regions, Economic Systems 39 (1), 43-58.

DI PIETRO G., URWIN P. (2003), Intergenerational mobility and occupational status in Italy, Applied Economics Letters 10 (12), 793-797.

DIETRICH H., MÖLLER J. (2016), Youth unemployment in Europe - business cycle and institutional effects, International Economics and Economic Policy 13, 5-25.

EICHHORST W., NEDER F. (2014), Youth unemployment in Mediterranean countries, IZA Policy Paper 80, Retrieved from: www.iza.org.

EMMENEGGER P., HÄUSERMANN S., PALIER B., SEELEIB-KAISER M. (2012), The age of dualization: the changing face of inequality in deindustrializing societies, Oxford University Press, Oxford.

ESPING-ANDERSEN G. (1999), Social foundations of postindustrial economies, Oxford University Press, Oxford.

EUROPEAN UNION (2013), European Economy: Macroeconomic Imbalances - Italy 2013, European Commission, Brussels.

FELICE E. (2007), Divari regionali e intervento pubblico: per una rilettura dello sviluppo in Italia, II Mulino, Bologna.

FELLINI I. (2015), Una "via bassa" alla decrescita dell'occupazione: il mercato del lavoro italiano tra crisi e debolezze strutturali, Stato e mercato 105 (3), 469-508.

FERRIE J. E. (2001), Is job insecurity harmful to health?, Journal of the Royal Society of Medicine 94 (2), 71-76.

FRATESI U., PERCOCO M. (2014), Selective migration, regional growth and convergence: evidence from Italy, Regional Studies 48 (10), 1650-1668.

FULLER C. (2014), Social Capital and the role of trust in aspirations for higher education, Educational Review 66 (2), 131-147.

FULLIN G., REYNERI E. (2015), Mezzo secolo di primi lavori dei giovani. Per una storia del mercato del lavoro italiano, Stato e mercato 105 (3), 419-468.

FURLONG A. (2006), Not a very NEET solution: representing problematic labour market transitions among early school-leavers, Work, Employment and Society 20 (3), 553-569.

FURLONG A. (2008), The Japanese hikikomori phenomenon: acute social withdrawal among young people, The Sociological Review 56 (2), 309-325.

GASPANI F. (2019), Young adults NEET and everyday life: time management and temporal subjectivities, Young 27 (1), 69-88.

GENDA Y. (2007), Jobless youths and the NEET problem in Japan, Social Science Japan Journal 10 (1), 23-40.

GORARD S. (2010), School experience as a potential determinant of post-compulsory participation, Evaluation \& Research in Education 23 (1), 3-17.

HANSEN L. P. (1982), Large sample properties of generalized method of moments estimators, Econometrica 50 (4), 1029-1054.

HARPER R. (2002), The measurement of Social Capital in the United Kingdom, Office for National Statistics, Retrieved from: www.oecd.org.

HODKINSON P., SPARKES A. C. (1997), Careership: a sociological theory of career decision making, British Journal of Sociology of Education 18 (1), 29-44.

ISTANCE D., REES G., WILLIAMSON H. (1994), Young people not in education, training or employment in South Glamorgan, South Glamorgan Training and Enterprise Council, Cardiff.

ISTRATE M., HOREA-SERBAN R., MUNTELE I. (2019), Young Romanians' transition 
from school to work in a path dependence context, Sustainability 11 (5), 1254.

ITALIA LAVORO (2011), I giovani NEET in Italia. Un'analisi territoriale, Bollettino No. 25, Italia Lavoro, Rome.

JOHNSON P., ZIMMERMANN K. F. (eds.) (2008), Labour markets in an ageing Europe,

Cambridge University Press, Cambridge.

KRAAK A. (2013), State failure in dealing with the NEET problem in South Africa: which way forward?, Research in Post-Compulsory Education 18 (1-2), 77-97.

MARSHALL K. (2012), Youth neither enrolled nor employed, Perspectives on Labour and Income 24 (2), 1-15.

MENCARINI L., PAILHÉ A., SOLAZ A., TANTURRI M. L. (2017), The time benefits of young adult home stayers in France and Italy: a new perspective on the transition to adulthood?, Genus 73 (1), 6.

MINISTRY OF LABOR AND SOCIAL POLICIES (2014), Piano di attuazione italiano della Garanzia per i Giovani, Ministero del Lavoro e delle Politiche Sociali, Retrieved from: www.garanziagiovani.gov.it.

MUSSIDA C., SCIULLI D. (2018), Labour Market Transitions in Italy: the Case of the $N E E T$, in: Malo M. A., Moreno Mínguez A. (eds.), European Youth Labour Markets: Problems and Policies, Springer, Cham, pp. 125-142.

NALDINI M. (2003), The family in the Mediterranean welfare states, Routledge, London. ODOARDI I. (2020), Can parents' education lay the foundation for reducing the inactivity of young people? A regional analysis of Italian NEETs, Economia Politica 37, 307-336. ODOARDI I., MURATORE F. (2018), The Italian regional dualism: A MARS and panel data analysis, The Review of Regional Studies 48 (3), 323-346.

ODOARDI I., MURATORE F. (2019), The North-South divergence in Italy during the Great Recession, The Manchester School 87 (1), 1-23.

OECD (2017a), Education at a glance 2017: OECD indicators, OECD Publishing, Paris. OECD (2017b), Education policy outlook - Italy, OECD Publishing, Paris.

OECD (2018), Education at a glance 2018: OECD indicators, OECD Publishing, Paris.

PASTORE F. (2015), The European Youth Guarantee: labor market context, conditions and opportunities in Italy, IZA Journal of European Labor Studies 4, 11.

PATTON W., DONOHUE R. (2001), Effects on the family of a family member being long term unemployed, Journal of Applied Health Behaviour 3 (1), 31-39.

PEMBERTON S. (2008), Tackling the NEET generation and the ability of policy to generate a 'NEET' solution-Evidence from the UK, Environment and Planning C: Government and Policy 26 (1), 243-259.

PUTNAM R. D., LEONARDI R., NANETTI R. Y. (1993), Making Democracy Work: Civic Traditions in Modern Italy, Princeton University Press, Princeton, NJ.

QUINTINI G., MANFREDI T. (2009), Going separate ways? School-to-work transitions in the United States and Europe, OECD Social, Employment and Migration Working Papers 90, OECD Publishing, Paris.

RAHMAN K. M. (2007), NEETs' challenge to Japan: causes and remedies, Japanstudien 18 (1), 221-244.

SALVATI L. (2013), 'North of the south' or 'south of the north'? Revisiting the spatiallycomplex economic divide in Italy, Journal of Urban and Regional Analysis 5 (1), 65-76. Torino. SALVEMINI G. (1955), Scritti sulla questione meridionale (1896-1955), G. Einaudi,

SARACENO C. (2015), Il lavoro non basta. La povertà in Europa negli anni della crisi, Feltrinelli, Milan.

SCARPETTA S., SONNET A., MANFREDI T. (2010), Rising youth unemployment during the crisis: How to prevent negative long-term consequences on a generation?, OECD Social, Employment and Migration Working Papers No. 106, OECD Publishing, Paris.

SERGI V., CEFALO R., KAZEPOV Y. (2018), Young people's disadvantages on the labour market in Italy: reframing the NEET category, Journal of Modern Italian Studies 23 (1), 41-60. 
SERRACANT P. (2014), A brute indicator for a NEET case: genesis and evolution of a problematic concept and results from an alternative indicator, Social Indicators Research 117, 401-419.

SILVER H. (1994), Social exclusion and social solidarity: three paradigms, International Labour Review 133 (5-6), 531-578.

SOCIAL EXCLUSION UNIT (1999), Bridging the gap: new opportunities for 16-18 year olds not in education, employment or training, The Stationery Office, London.

STAIGER D., STOCK J. H. (1997), Instrumental variables regression with weak instruments, Econometrica 65 (3), 557-586. London.

STANDING G. (2011), The precariat: The new dangerous class, Bloomsbury Academic, 912.

SULLIVAN A. (2001), Cultural capital and educational attainment, Sociology 35 (4), 893-

THOMPSON R. (2011), Individualisation and social exclusion: the case of young people not in education, employment or training, Oxford Review of Education 37 (6), 785-802.

TOMASSINI C., WOLF D. A., ROSINA A. (2003), Parental housing assistance and parent-child proximity in Italy, Journal of Marriage and Family 65 (3), 700-715.

TONIOLO G. (ed.) (2013), The Oxford Handbook of the Italian Economy Since Unification, Oxford University Press, Oxford.

WOLFF E. N. (2000), Human capital investment and economic growth: exploring the cross-country evidence, Structural Change and Economic Dynamics 11 (4), 433-472.

YATES S., PAYNE M. (2006), Not so NEET? A critique of the use of 'NEET' in setting targets for interventions with young people, Journal of Youth Studies 9 (3), 329-344.

Initial submission: 24.09.2019

Revised submission: 08.03.2020

Final acceptance: 29.05 .2020

Correspondence: University of Chieti-Pescara, Viale Pindaro 42, 65127, Pescara, Italy.

Email: iacopo.odoardi@unich.it 
